\title{
Good Literary Practices in the Secondary Education Classroom: Reading the Classics from a Bimodal Perspective
}

\author{
María-José Molina-García*, María Rosa Márquez Clares and Pilar Núñez-Delgado \\ Department of Language and Literature, University of Granada, Spain
}

\begin{abstract}
This research, which is framed in an $\mathrm{R}+\mathrm{D}$ project on Literary Education, aims to explore and validate strategies to bring classic readings closer to Secondary Education students. Specifically, this study focuses on the design of the didactic program. The methodology adopts a bimodal approach based on collaborative group learning and problem solving. The experimental subjects are students between 15 and 16 years old, and the materials are based on the use of ICT tools and the design of a blog that seeks to introduce classic books in a more motivating way and to enhance the axiological dimension of Literature (Arriasecq y Santos, 2017). The leading figure of Emilia Pardo Bazán and two of her least popular works (Gol, 2016), which can be found in La Biblioteca de la Mujer (Women's Library) that she founded in 1892, have been chosen as philological-culinary projects (Teophano, 2016). These works reflect the author's concern for social enculturation and specially her modern ideas on female identity (Moreno, 2016), a topic which can engage students to whom the proposal is addressed. The project objective is motivating students towards reading by using nontraditional texts, such as recipe books (Simón Palmer y Sauret Guerrero, 2010), and introducing socially attractive works to improve their critical thinking and contribute to their Values Education. Thus, we can achieve a productive Literary Education that builds thematic bridges connecting with previous times and collectives.
\end{abstract}

Keywords: active methodologies; ICT; literary education; Secondary Education.

\section{Introduction}

Population's interest in reading is undoubtedly decreasing (especially when it comes to classics of literature) at any educational level and moment of life, and particularly during Secondary Education. Unfortunately, this is a tendency that sometimes of Language and Literature teachers do not know how to turn over. We tend to demand from our students, (regardless of their age, interests, and character), to read books that sometimes turn out to be dull even to the teachers themselves, who are quite more experienced in these contents. Teachers frequently consider necessary to know the classics and their contents, so it is required to read in the classroom Spanish classic books such as Don Quixote, The Tree of Knowledge, or Blind Sunflowers. However, although readings these classics is a must, this

\section{info@icate.org}


should be done in a way that adjusts to the maturity of the students and their personal interests. To make students participants and protagonists of their teaching-learning process, we must first motivate them through methods and resources that bring them closer to literature, such as recommending them short interesting readings to have a first contact with literature or books related to their literary preferences, or with projects that awaken their curiosity, as the philological-culinary project presented in this article (Aguirregoitia Martínez y Fernández Poyatos, 2015).

The importance of the classics lies in their timeless themes. They are easily extrapolated to any period of history, and therefore, they relate to the present time, giving solutions or providing comfort for the daily affections. This is the case of the author we selected, Emilia Pardo Bazán, who, although she is a contemporary of the 19th century (Baquero Goyanes, 1955), shows great foresight in problems that even today are relevant, such as gender inequality, xenophobia, classism, and the need for violence prevention, justice and freedom (Parra, 1993). Although she is one of the few female authors frequently studied in the Spanish Language and Literature classroom (Longhurst, 2008), her bibliographic production has not been analyzed in depth. Her work tends to be reduced to The House of Ulloa and, to a lesser extent, Mother Nature, as an epigraph of Realism and Naturalism (Rojas Yedra, 2017), but her literary production is much broader, being, indeed, some of her works susceptible to be forgotten for not adapting to what is expected from an author, especially in the case of an 19th century author (Sotelo Vázquez, 1998).

The complete production of Pardo Bazán is little known and provides the teacher with the possibility of working in the classroom the social enculturation to which all of us are submitted since we live in society (Martín-Lorente y Fernández, 2014). Moreover, the creation of The Women's Library, with her approaches to female identity (Rodríguez, 1982), and the ideas far ahead of her time that she presents not only in this work, but in her entire bibliography (Sánchez, 2007), make her a relevant example of enlightenment and progress.

\section{Methods}

\subsection{Sample}

A non-probabilistic convenience sampling method has been used, selecting a Compulsory Secondary Education classroom of fourth-year students, which is composed of sixteen boys and fourteen girls aged 15-16, two of them with special needs. One of these students is diagnosed with moderate-high intellectual giftedness, obtaining a IQs of 132 , and does not present low self-esteem or behavioral problems in the classroom or with his peers, with whom he gets on well, helping them even without the academic tasks. The second student with special needs presents a mild hearing loss (between 30-40 dB), so he does not perceive distant speech correctly and may be difficult for him to understand lectures and conversations in noisy environments; he wears a hearing aid and requires to be placed in the front row so he can read the teacher's lips, but he can follow the explanations during the classes. For group activities, students will be divided into five heterogeneous groups composed by six members.

All of them study in a High School in Melilla, a Spanish city located in North Africa, which consists of approximately 85000 people according to the last published census (INE, 2019). Five different cultural communities coexist in this city: people of European, Berber, Jewish, Gypsy and Hindu origin. The first three groups constitute most of the population. The special

$$
\text { info@icate.org }
$$


location of the city between Africa and Europe and the constant immigration flows has a decisive socio-cultural and economic influence; the immediate impact on education is the formation of culturally diverse classrooms.

According to the Education Center Project (ECP) for the 2019/2020 school year, the students belong to the upper-middle class with parents who have achieved a certain educational level, including university studies. Data indicate that school failure decreases in this context and that these students have reference books at their disposal; the majority have an adequate place to study at home and a library in some cases. However, these students do not have consistent reading habits as they do not express interest towards literary texts and particularly in classical works.

\subsection{Instrument}

The instrument designed as a dependent variable is a didactic proposal for intervention within the framework of the Organic Law 8/2013 for the Improvement of Educational Quality (abridge in Spanish as LOMCE). This law currently governs Education in Spain, together with the Royal Decree-Laws (RD) and Orders of the Ministry of Education, Culture and Sports (MECS) oriented to the educational stage of Compulsory Secondary Education, always framed within the LOMCE, which are included in the following table:

Table 1: Relations between RD and MECS Orders for Compulsory Secondary Education in Spain

\begin{tabular}{|l|l|}
\hline $\begin{array}{l}\text { Royal Decree 1105/2014, dated 26 } \\
\text { December. }\end{array}$ & $\begin{array}{l}\text { It stablishes the basic curriculum for Compulsory Secondary } \\
\text { Education and Baccalaureate }\end{array}$ \\
\hline $\begin{array}{l}\text { Amendment of errors of Royal Decree } \\
\text { Oro5/2014, dated 26 December }\end{array}$ & $\begin{array}{l}\text { The basic curriculum of Compulsory Secondary Education } \\
\text { and Baccalaureate is established. }\end{array}$ \\
\hline Order ECD/65/2015, dated 21 January & $\begin{array}{l}\text { It describes the relationships between competencies, content } \\
\text { and evaluation criteria for Primary Education, Compulsory } \\
\text { Secondary Education and Baccalaureate. }\end{array}$ \\
\hline Order ECD/1361/2015, dated 3 July & $\begin{array}{l}\text { It amends the Order EDU/849/2010, of March 18, which } \\
\text { regulates the organization of the education of students in } \\
\text { need of educational support and regulates the educational } \\
\text { guidance services in the management area of the Ministry of } \\
\text { Education in the cities of Ceuta and Melilla. }\end{array}$ \\
\hline $\begin{array}{l}\text { Amendment of errors of the Order } \\
\text { ECD/1361/2015, dated 3 July }\end{array}$ & $\begin{array}{l}\text { This Order establishes the curriculum of Compulsory } \\
\text { Secondary Education and Baccalaureate for the management } \\
\text { area of the Ministry of Education, Culture and Sport, and } \\
\text { regulates its implementation, as well as the continuous } \\
\text { evaluation and certain organizational aspects of the different } \\
\text { educational stages. }\end{array}$ \\
$\begin{array}{l}\text { By which the curriculum of Compulsory Secondary } \\
\text { Education and Baccalaureate is established for the } \\
\text { management area of the Ministry of Education, Culture and } \\
\text { sport, and its implementation is regulated, as well as the } \\
\text { continuous evaluation and certain organizational aspects of } \\
\text { the stages. }\end{array}$ \\
\hline
\end{tabular}

Source: Own elaboration

i n f o @ c a t e.org 
For this educational stage, the legal regulations prescribe the design of programs based on competencies, seeking to achieve key competencies. In the program elaborated in this research, it is possible to contribute to the development of the following competences: Linguistic Communication Competence (LCC), Digital Competence (DC), Learning to Learn Competence (LLC), Social and Civic Competence (SCC), Sense of Initiative and Entrepreneurship Competence (SIEC), Cultural Awareness and Expression Competence (CAEC) and Mathematical Competence and Basic Competence in Science and Technology (MCBCST).

The general contents, which have been designed following the law, have been classified in for blocks and have been related to specific contents. At the same time, the current legal framework also recommends including transversal and interdisciplinary contents. All of them are exposed in the following table:

Table 2: List of General, Specific, Transversal and Interdisciplinary Contents

\begin{tabular}{|c|c|}
\hline \multicolumn{2}{|c|}{ Block 1: Oral communication. Listening and speaking } \\
\hline General Contents & Specific Contents \\
\hline $\begin{array}{l}\text { 1. Comprehensive understanding: recognition of the } \\
\text { speaker's communicative intention, identification of } \\
\text { the subject matter of the text, differentiation from } \\
\text { main and secondary ideas and obtaining concrete } \\
\text { information. } \\
\text { Interpreting the meaning of the text: determining the } \\
\text { speaker's attitude. }\end{array}$ & $\begin{array}{l}\text { 1.1 Analysis of the bibliography of Emilia Pardo Bazán, } \\
\text { specifically the novel The House of Ulloa (1886-87) and } \\
\text { the essays Old Spanish cuisine (1913) and } \\
\text { Modern Spanish cuisine (1918) } \\
1.2 \text { Identification of the intention, theme, ideas, } \\
\text { meaning and interpretation of the author and these } \\
\text { works. }\end{array}$ \\
\hline \multicolumn{2}{|c|}{ Block 2: Written communication. Reading and writing } \\
\hline General Contents & Specific Contents \\
\hline $\begin{array}{l}\text { 2. Knowledge and progressive use of comprehension } \\
\text { techniques and strategies in all phases of the reading } \\
\text { process: before, during and after reading }\end{array}$ & $\begin{array}{l}2.1 \text { Reading fragments of The House of Ulloa and the } \\
\text { essays Old Spanish cuisine and Modern Spanish cuisine } \\
\text { applying the phases of the reading process }\end{array}$ \\
\hline $\begin{array}{l}\text { 3. A progressively critical and thoughtful attitude } \\
\text { towards reading, organizing ideas reasonably so they } \\
\text { can be exposed, and respecting others' ideas. }\end{array}$ & $\begin{array}{l}\text { 3.1 Analysis of the social differences between Emilia } \\
\text { Pardo Bazan's context described in her literary works } \\
\text { and the present time }\end{array}$ \\
\hline $\begin{array}{l}\text { 4. Use of dictionaries, libraries and Information and } \\
\text { Communication Technologies as a source of } \\
\text { information by themselves. }\end{array}$ & $\begin{array}{l}\text { 4.1 Use of dictionaries and encyclopedias on different } \\
\text { platforms to expand the knowledge acquired in the } \\
\text { classroom }\end{array}$ \\
\hline $\begin{array}{l}\text { 5. Developing interest in written composition as a } \\
\text { source of information and learning, as a way of } \\
\text { communicating one's experiences and knowledge, } \\
\text { and as an instrument for personal and professional } \\
\text { development. }\end{array}$ & $\begin{array}{l}\text { 5.1 Rewriting recipes (considered a prescriptive textual } \\
\text { typology) of Old Spanish cuisine and Modern Spanish } \\
\text { cuisine using modern expressions and measures }\end{array}$ \\
\hline
\end{tabular}

${ }^{1}$ Translator's notes: neither of these two culinary works has been translated. The original Spanish titles are La cocina española Antigua (1913) and La cocina española moderna (1918).

i n fo@icate.org 


\begin{tabular}{|l|l|}
\hline \multicolumn{1}{|c|}{ General Contents } & \multicolumn{1}{c|}{ Specific Contents } \\
\hline $\begin{array}{l}\text { 6. Observation, consideration, and explanation of the } \\
\text { different meanings of words and expressions in an } \\
\text { oral or written discourse. }\end{array}$ & $\begin{array}{l}\text { 6.1 Appreciation of the differences between written and } \\
\text { spoken language in different texts. }\end{array}$ \\
\hline $\begin{array}{l}\text { 7. Use of dictionaries and other reference sources, on } \\
\text { paper and in digital format, to investigate about the } \\
\text { rules and non-normative use of words, and learn how } \\
\text { to interpret linguistic information provided by } \\
\begin{array}{l}\text { Language dictionaries: grammar, semantics, register } \\
\text { and use. }\end{array}\end{array}$ & $\begin{array}{l}7.1 \text { Use of dictionaries on different platforms to learn } \\
\text { about linguistic and orthographic differences, as well as } \\
\text { their evolution and divergences. }\end{array}$ \\
\hline $\begin{array}{l}\text { 8. Knowledge, use and analysis of orthographic and } \\
\text { grammatical rules, recognizing their social value and } \\
\text { the need to follow them in writing for efficient } \\
\text { communication. }\end{array}$ & $\begin{array}{l}8.1 \text { Correct spelling and orthography in written } \\
\text { communication } \\
8.2 \text { Correct use of grammar in written communication }\end{array}$ \\
\hline $\begin{array}{l}\text { 9. Knowledge of the different registers and factors } \\
\text { that affect the use of language in different social } \\
\text { environments and recognition of the importance of } \\
\text { using the appropriate register according to the } \\
\text { communicative situation. }\end{array}$ & $\begin{array}{l}\text { 9.1 Appreciation of the language differences of the main } \\
\text { characters of The House of Ulloa according to their } \\
\text { social class }\end{array}$ \\
\hline
\end{tabular}

\section{Block 4: Literary Education}

10. Introduction to the Spanish literature of the 18th, 19 th and 20th centuries using texts.

11. Reading and understanding of literary texts belonging to the realist/naturalist movement, recognizing the intention of the author, the theme, the formal features of the genre to which they belong and the relationship between the content and the socio-cultural context they are framed.

12. Consulting various sources of information for their academic tasks and cited these sources properly.
10.1 Interpretative reading of fragments of emblematic texts of the Spanish Realism and Naturalism.

10.2 Critical analysis of texts considering the social context.

10.3 Comparison of the text with other contemporary and current texts.

11.1 Understanding of fragments of Realism and Naturalism texts and their formal structure.

12.1 Research on the historic period and its relationship with the literature, philosophy, and art development.

\section{3.- Transversal contents}

- Values such as equality, justice and freedom appear explicitly in the Emilia Pardo Bazan's works, values embodied in the creation of the The Women's Library in which the essays studied in class were found: Old Spanish cuisine and Modern Spanish cuisine.

- Prevention of violence, racism and xenophobia.

\section{4.- Interdisciplinary Contents}

- The study of Emilia Pardo Bazán and her realistic and naturalistic work is essential in the Literary Education, but this knowledge is related to other subjects: Philosophy, since the Naturalism as a movement has philosophical origins ; History, since the analogies appearing in her works can be examined; History of Art, analyzing the similarities between the realistic and naturalistic development in the artistic expression and Literature; and Scientific Culture through the use of the measures and instructions appearing in the recipes, and the opportunity to work with concepts such as nutritional

info@icate.org 
value or gastronomy.

Source: Own elaboration

The activities designed to achieve the competencies and explain the programmed contents, are classified in: initiation activities (oriented to the analysis of the previous students' knowledge so that the teacher can adapt his/her performance thanks to a certain curricular flexibility; motivation activities (designed to motivate the students and connect with their interests, in addition to being closely linked to the Competence for Learning to Learn); development activities (oriented to consolidate the acquisition of the contents explained in the classroom); extension activities (to extend the knowledge acquired in the classroom) and reinforcement activities (adaptable to the individual circumstances for those students who need academic support to achieve the proposed competences). Some examples of all these types of activities are presented in the following table:

Table 3: Sample of different types of activities.

\begin{tabular}{|c|c|}
\hline Initiation activities & $\begin{array}{l}\text { Brainstorming on initial ideas on Realism and Naturalism } \\
\text { Debate on women's role in Literature } \\
\text { Brainstorming on students' prior knowledge of Emilia Pardo } \\
\text { Bazán } \\
\text { Group tests on worked contents }\end{array}$ \\
\hline Motivational activities & $\begin{array}{l}\text { Collective synopsis of each classroom session } \\
\text { Elaboration of digital concept maps, their projection and } \\
\text { exposition afterwards. } \\
\text { Visit to the Hospitality Management School or similar } \\
\text { institutions for basic culinary knowledge and typical food } \\
\text { from different cultures. }\end{array}$ \\
\hline Development Activities & $\begin{array}{l}\text { Search for videos on the web about Realism and Naturalism } \\
\text { (historical context, literary characteristics, outstanding } \\
\text { figures) } \\
\text { Elaboration of Prezzis } \\
\text { Creation of timescales } \\
\text { Intertextuality with other artistic manifestations (pictorial } \\
\text { artworks) } \\
\text { Participation in a collaborative blog designed ad hoc } \\
\text { (comments, interesting information...) } \\
\text { Presentation of Old Spanish cuisine and Modern Spanish } \\
\text { cuisine and selection of recipes depending on students' } \\
\text { preferences. } \\
\text { Analysis of time and social context of the prologue of the } \\
\text { work. } \\
\text { Analysis of the lexicon of these works. } \\
\text { Identification of the measures used in the recipes of these } \\
\text { works. }\end{array}$ \\
\hline Extension activities & $\begin{array}{l}\text { Comparative debates on previous periods of Literature. } \\
\text { Preparation of recipes (adapting the orthographic } \\
\text { characteristics to the present time) and oral and written } \\
\text { explanations. } \\
\text { Reading of literary texts about explained contents. }\end{array}$ \\
\hline Reinforcement activities & $\begin{array}{l}\text { Comments on videos } \\
\text { Viewing of video scripts } \\
\text { Elaboration of concept maps on paper and exposition. }\end{array}$ \\
\hline
\end{tabular}

info@icate.org 


\section{3rd International Conference on Advanced Research in Teaching and Education}

Source: Own elaboration

\subsection{Process}

Using ICT in the classroom enhances the students' acquisition of significant knowledge (Arriassecq y Santos, 2017). Using a digital blackboard and different computer applications and environments for the development of activities, facilitates the learning process. Tailoring around their interests, which usually are related with computers when students are teenagers, we may awake their interest in Language and Literature.

The implementation of active methodologies engages students and make them to enjoy the time they spent in the Language and Literature classroom; the programmed activities are oriented to awake their motivation so that they develop an interest in authors and literary movements. (Barca Lozano, 2009). From these methodologies and problem-solving tasks, students find themselves in an educational environment which encourages them to think about in their long-term learning and not only to pass the subject, leaving aside others methodologies that just demand to solve mechanically repetitive exercises without room for interpretation or that make students adopt a passive role. This approach aims to present unpredictable problems that may arise both at school and in real life to the students and provide them with the necessary tools to solve these issues by themselves. Therefore, it is very important to work with different media and different subjects that complement, through interdisciplinary, the task of the classroom of Language and Literature to achieve comprehensive learning.

The combination of active methodologies, such as collaborative learning and problem solving, places the student as the protagonist of the teaching-learning process, so that he/she can apply the acquired knowledge to the skills training process and the assimilation of the contents. These methodologies are based on important methodological principles, such as student motivation and self-esteem (Fernández-Lasarte, Ramos Díaz, Goñi Palacios and Rodríguez Fernández, 2019), interdisciplinarity (Martín-Piñol, Calderón-Garrido, and Gustems-Carnicer, 2016), participative and collaborative learning (Ortega, 2016), and value education and critical thinking (Laiton-Poveda, 2010), among others.

\subsection{Evaluation and data collection}

The students' evaluation criteria and learning standards (also included in the legal framework) can be related to the proposed program topic. Therefore, these evaluation criteria and learning standards can be classified according to their content, as shown in the table below:

Table 4: Relationship between Evaluation Criteria and Learning Standards, and their classification in content blocks

\begin{tabular}{|l|l|}
\hline Evaluation criteria & Learning standards \\
\hline
\end{tabular}

info@icate.org 


\section{Block 1: Oral communication. Listening and speaking}

1. Properly understanding, interpretation and evaluation of oral texts coming from personal, academic, social and work environments, so that students get the complete sense of the text by identifying relevant information, extracting specific information, making inferences, determining the speaker's attitude and evaluating some aspects of their structure and content.

1. a. Ability to understand and evaluate oral texts in the school and social environment, finding out the complete sense of the texts, identifying relevant information and extracting concrete information.

1. b. Determining the speaker's attitude in naturalistic and realistic oral texts and evaluate some aspects of their structure and content.

3. To understand the sense and the communicative intention of the debates, colloquiums, and spontaneous conversations by identifying, interpreting, and assessing the communicative intention, the divergent positions and assuming the basic norms that regulate social communication.

3. a. Participation in classroom debates respecting different opinions and turns.
1.2. The student anticipates ideas and infers data from the issuer and from the text by analyzing nonverbal sources.

1.3. The student recognizes the structure of oral messages coming from personal, academic, social, and work environments.

1.4. To retain relevant information.

1.5. Finding specific information.

1.6. Identification of the structure of oral messages and the interrelationship between discourse and context.
3.1. The student listens, observes and understands the sense of debates, colloquiums and spontaneous conversations by identifying the relevant information, determining the topic and recognizing the communicative intention and the position of each participant, as well as the formal and content differences that regulate formal and spontaneous communicative exchanges.

3.3. To observe and analyze the interventions of each participant in a debate, colloquium, or spontaneous conversation, analyzing the tone, the language, the content, and the level of respect for the others' opinions.

3.4 To identify the purpose, thesis, and arguments of the participants in debates, discussions, and interviews from the audiovisual media, critically evaluating specific aspects of their structure and content.

3.5. The student recognizes and adopts the rules of interaction, intervention and courtesy that regulate the debates and any oral communicative interaction.

4.3. The student acknowledges the own errors and other people's mistakes in the oral production based on the usual practice of evaluation and self-evaluation, proposing solutions to improve them. progressively evaluate the exposition skills, the adequacy, coherence and cohesion of the content of one's own and peers' oral productions, as well as the prosodic aspects and the non-verbal elements (gestures, movements, look...).

4. a. Improvement in oral presentations skills through constant practice, adapting their discourse and gestures to the context and the theme. 
1. To apply different reading comprehension strategies to texts from personal, academic, social, and work environments and to texts with a narrative, descriptive, expository, and argumentative intention.

1. a. Using reading strategies for the comprehension of realistic and naturalistic works during the reading process.

1. b. Using reading strategies for the interpretation of realistic and naturalistic works during the reading process.
3. To develop a critical attitude when reading any type of text or literary work through a reflective reading that allows identifying positions of agreement or disagreement, always respecting the others' opinions.

3. a. To develop a critical attitude when reading realistic and naturalistic works through reflective reading.

3. b. Respect for others' opinions

4. Selecting the knowledge obtained from libraries or any other information source on paper or in digital format, integrating it into a continuous learning process.

4. a. To look for extra information to expand the knowledge explained in the classroom

7. To value the importance of reading and writing as tools for learning and as a stimulus for personal development.

7. a. Creating your own texts with realistic or naturalistic characteristics.
1.1. Understanding different types of texts, carrying out different reading strategies depending on the objective and type of text, rethinking previous knowledge, working on comprehension errors, and understanding the global meaning of the text.

1.2. The student identifies, relates, and orders the explicit information of the texts and identifies the implicit idea or ideas, being able to explain the significant characteristics of a text.

1.3. The student deduces the relevant information of the texts, identifying the main idea and the secondary ideas, and establishing relations between them.

1.5. To understand the meaning of cultured language words, incorporating them to their vocabulary and recognizing the importance of enriching it to express themselves with accuracy and precision.

3.1. The student identifies and expresses the positions of agreement and disagreement on partial or global aspects of a text

3.2. The student develops its own interpretation of the meaning of a text

\subsection{Respect for others' opinions}

4.1. To consult autonomously diverse sources of information, integrating the results of this research in their oral or written discourses

4.2. The student knows and handles different types of dictionaries, printed or in digital format.

7.1. The student produces diverse texts, recognizing the writing as an instrument to organize the ideas.

7.2. To use formal language words in writings, incorporating them to their vocabulary and recognizing the importance of learning new words to express themselves orally and in writing with accuracy and precision.

7.3. The student appreciates creativity and progressively incorporates a creative attitude towards writing.

7.4. The student handles and uses Information and Communication Technology tools. The student participates, exchanges opinions, comments and evaluates other people's writings or write his/her own texts.

Block 3: Language Knowledge

info@icate.org 
4. Identifying the different meaning of words or expressions according to the communicative intention in the oral or written discourses.

4. a. Discern the meaning of words.

5. Using dictionaries and other reference sources correctly and effectively, both on paper and in digital format, to resolve doubts about the correct use of the language developing autonomous learning.

5. a. Effective use of the paper dictionaries to solve doubts about the differences between current Spanish and the Spanish used in Emilia Pardo Bazan's texts.

5. b. Effective use of different reference sources in digital format to resolve doubts about Realism and Naturalism.

7. To apply the knowledge of the language to solve problems of comprehension and expression of oral and written texts, and to develop autonomously evaluation skills to assess one's own and other people's texts.

7. a. To work out the meaning of parts of the text by using the context.

10. Recognizing and using the different linguistic registers according to the social areas, valuing the importance of adapting the appropriate register to the situation.

10. a. To adapt the use of language to the context and situation.
4.2. The student explains the meaning of words accurately, using the appropriate meaning in relation to the context in which they appear.

5.1. To use dictionaries and other reference sources available on paper or in digital format, effectively resolving their doubts about the correct use of the language and progressing in autonomous learning.

7.1. The student looks over his/her oral and written speeches, correctly applying orthographic and grammatical rules, and recognizing their social value for efficient communication.

10.1. The student identifies linguistic registers in oral or written texts according to the communicative intent and social use.

10.2. Recognition of the importance of using the appropriate register for each communicative situation and adapts the register in his/her oral and written speeches.

\section{Block 4: Literary Education}

1. To read and understand autonomously Spanish and universal literature works of different periods and youth literature. These works should be close to one's own tastes and interests, so the student involves in in these readings.

1. a. Read literary texts autonomously for pleasure.

4. To read, understand and comment on realist/naturalist texts, both in its very formal and popular manifestations (serialized novels, pamphlets...), relating all the formal and content elements with the author's communicative intention and with the socio-cultural context in which they appear, as well as their relevance for later literary manifestations.

1. a. Reading of representative texts of the Realism and Naturalism movements

1. b. Understanding representative texts of the Realism and Naturalism movements.

1. c. Commenting on representative texts of Realism and Naturalism movements.

1. d. Identifying the author's intention when reading realistic and naturalistic texts, their theme, and their structure according to
1.1. The student reads and understands literary works close to their tastes and hobbies, showing a higher level of interest and autonomy

1.3. The student stablishes relationships and associations between works, focusing on the theme or themes that the student finds interesting.

4.1. The student reads, understands and explains a realist/naturalist novel adapted to his/her reading maturity, summarizing the content, and identifying the characteristics of its genre and the socio-cultural context. 


\begin{tabular}{|c|c|}
\hline $\begin{array}{l}\text { their genre. } \\
\text { 1. e. Identification of the most relevant } \\
\text { formal features of realistic and naturalistic } \\
\text { texts. } \\
\text { 1. f. Relate realistic and naturalistic texts } \\
\text { to their sociocultural context. }\end{array}$ & \\
\hline $\begin{array}{l}\text { 7. Searching and adequately citing different } \\
\text { information sources to carry out academic work on a } \\
\text { topic of the literature curriculum, on paper or digital } \\
\text { support, adopting a critical and personal point of view } \\
\text { and using information technologies. } \\
\text { 7. a. To consult adequately varied } \\
\text { information sources to carry out a school } \\
\text { project, in paper or digital support, on } \\
\text { Realism and Naturalism. } \\
\text { 7.b. Citing adequately various sources of } \\
\text { information to carry out a school project, on } \\
\text { paper or digital format, about Realism and } \\
\text { Naturalism. } \\
\text { 7.c. To adopt a personal point of view } \\
\text { when elaborating a schoolwork on Realism } \\
\text { and Naturalism. } \\
\text { /. d. Use information technology resources to } \\
\text { design and carry out a school project on } \\
\text { Realism and Naturalism. }\end{array}$ & $\begin{array}{l}\text { 7.1. The student consults and adequately cites } \\
\text { several sources of information to develop in writing a } \\
\text { topic related to the Literature curriculum in a rigorous, } \\
\text { clear, and coherent way. } \\
\text { 7.2. In written and oral works, the student can } \\
\text { provide conclusions and personal and critical points of } \\
\text { view about the studied literary works, expressing } \\
\text { himself with rigor, clarity, and coherence. } \\
7.3 \text {. Using several Information and } \\
\text { Communication Technologies sources for the } \\
\text { realization of his academic tasks. }\end{array}$ \\
\hline
\end{tabular}

Source: Own elaboration

The following table shows the evaluation types and techniques, data collection instruments and the evaluation percentage assigned:

Table 5: Relationship between types of evaluation, techniques, instruments, and percentages applied in the didactic program.

\begin{tabular}{|c|c|c|c|}
\hline TYPE & TECHNIQUES & INSTRUMENT & PERCENTAGES \\
\hline Formative evaluation & Students' production & Reading Portfolio & $30 \%$ \\
\hline Formative evaluation & Direct Observation & Teacher's notebook & $30 \%$ \\
\hline Formative evaluation & Direct Observation & $\begin{array}{c}\text { Academic rubric to } \\
\text { stablish the assessment } \\
\text { criteria for the concept } \\
\text { map exposition }\end{array}$ & $30 \%$ \\
\hline Summative evaluation & Students' production & Written test & $30 \%$ \\
\hline
\end{tabular}

Source: Own elaboration

info@icate.org 


\section{3rd International Conference on Advanced Research in Teaching and Education}

\section{Results}

The results of this educational program are related to ICT so that the student can access them not only in the school, but also in his own home, the library, etc.

- Blog: In this blog the students have always available the theoretical contents explained in the classroom, resources and, in addition, it is a platform to share their own productions. The link to the reading portfolio is also available in the blog: https://laotraemiliapardobazan.blogspot.com/

- Reading Portfolio, where the readings offered to the students are collected and arranged following a Reading Plan; these have been selected because of their cultural and gastronomic content, conflictive gender situations and other transversal contents included in the didactic proposal and adapted to the student's tastes and interests. The topics of the books are diverse in order to cover the maximum possibilities and all the literary inclinations: https://trello.com/b/pVH0nbeW/portafolio-congreso

- Open access videos on diverse theoretical contents. The following video, which has been selected using videoscribe techniques, is about the Emilia Pardo Bazan's works. https://www.youtube.com/watch?v=PE97f5rZcQ teóricos acerca de diferentes aspectos. c

- Videoscribe on the Emilia Pardo Bazan's literary works. https://www.youtube.com/watch?v=Eh80eqzrnhc

- Prezzi to schematise the explained and worked contents: https://prezi.com/p/lo7nyzyfro/?present=1

- Digital conceptual map designed with the Genially application (https://www.genial.ly/es)

\section{Conclusion}

It is expected that students will enjoy literature through gastronomy in the Secondary Education classroom where the explained $\mathrm{R}+\mathrm{D}$ project will be carried out. Since the elaboration of recipes is a familiar concept to them (since to a different extend, we all carry out or have seen how it is done), we can show the students that Literature offers a wide range of options and includes multiple aspects that can make the students motivated when they choose according to their interests.

Apart from Emilia Pardo Bazan's texts on gastronomy and recipes, which are very outstanding options to work with in the classroom, there are other literary works related to Gastronomy and women that can be offered to the students available in The Women's Library (1913 and 1918) founded by her. Some of the examples of these texts are Like water for chocolate, by Laura Esquivel (1989), or, even, recipe books related to other attractive books for the students, such as A Feast of Ice and Fire, from the very popular saga A Song of Ice and Fire, by George R. R. Martin (1996); Nanny Ogg's Cookbook: A Useful and Improving Almanack of Information Including Astonishing Recipes from Terry Pratchett's Discworld,

\section{info@icate.org}


starring Tata Ogg, part of Terry Pratchett's Discworld saga; or from TV series, such as Bob's Burgers, The Bob's Burger Book. Real recipes for joke burgers; Feeding Hannibal: A Connoisseur's Cookbook, inspired by the Hannibal series; or the official recipe book of easygoing series such as Friends.

By introducing this variety of books to the students, we expect to stimulate their curiosity, a very important goal as we try to encourage them to train hard the linguistic competence. This purpose is crucial during the fourth year of Compulsory Secondary Education, since it is, stricto sensu, the final opportunity for many of them to take on reading, although this habit has been encouraged in previous years during compulsory and basic stages. Literature should be perceived by students as something more than just a set of mandatory texts; it should discover them a world of new experiences and, at the same time, relate them to their own reality. Students should be able to find in these books symbolism, criticism, and a reflection of the society at a certain time, and, thanks to this reading habit, they could exercise their critical thinking, improve skills and become a mature and functional adult able to live in society.

\section{Acknowledgment (TNR 12pt. bold)}

This paper is an output of the science project I+D+I PID2019-105913RB-I00 funded by the Ministry of Economy and Competitiveness

\section{References}

Aguirregoitia Martínez, A. y Fernández Poyatos, M. D. (2015). La gastronomía en la prensa española del siglo XIX/Gastronomy in the spanish press during the 19th century. Estudios Sobre El Mensaje Periodistico, 21(1), 17-33. Available: de https://search.proquest.com/docview/1713913191? accountid=1454

Arriassecq, I., y Santos, G. (2017). Nuevas tecnologías de la información como facilitadoras de aprendizaje significativo. Archivos De Ciencias De La Educación, 11(12) doi:http://dx.doi.org/10.24215/23468866e030

Baquero Goyanes, M. (1955). La novela naturalista española: Emilia Pardo Bazán. In Anales de la Universidad de Murcia. Filosofía y Letras. Universidad de Murcia, Secretariado de Publicaciones.

Barca Lozano, A. (2009). Perfiles motivacionales del alumnado de educación secundaria y rendimiento academico. Educação. Temática Digital, 10, 62. Available: https://search.proquest.com/docview/1442232285? accountid=14542

Esquivel, L. (1989). Como agua para chocolate. Debolsillo.

Fernández Lasarte, O., Ramos Díaz, E., Goñi Palacios, E., and Rodríguez Fernández, A. (2019). Estudio comparativo entre educación superior y educación secundaria: efecto del apoyo social percibido, el autoconcepto y la reparación emocional en el rendimiento académico. Educación $X X 1,22(2)$,

165-185. doi:http://dx.doi.org/10.5944/educXX1.22526 
Gol, J. (2016). Cocinas literarias: Breve perspectiva de la literatura gastronómica española a partir de seis obras fundamentales. Quimera, 392/393, 26-33. Available: de https://search.proquest.com/docview/1937398416? accountid=14542

Laiton-Poveda, I. (2010). Formación de pensamiento crítico en estudiantes de primeros semestres de educación superior. Revista Iberoamericana de Educación, 53(3), 1-7.

Ley Orgánica 8/2013, de 9 de diciembre, para la Mejora de la Calidad Educativa. (BOE núm. 295, de 10 de diciembre de 2013, 97858-97921).

Longhurst, C. A. (2008). El giro de la novela en España: Del Realismo al Modernismo en la narrativa española. Boletín De La Biblioteca De Menéndez Pelayo, Lxxxiv, 59-106. Available: https://search.proquest.com/docview/1626285654? accountid=14542

Martin, G.R.R. (1996). A Song of Ice and Fire. Gigamest.

Martín-Lorente, M., y Fernández, C. F. (2014). Aspectos de cultura y comunicación en el protocolo gastronómico y las prácticas de alimentación en diferentes etapas históricas/Aspects of culture and communication in the gastronomic protocol and the practices of alimentation in different historical stages. Historia y Comunicación Social, 19 , 831-842.

Available:

https://search.proquest.com/docview/1650978152?accountid=14542

Martín-Piñol, C., Calderón-Garrido, D., y Gustems-Carnicer, J. (2016). Interdisciplinariedad y tecnología en la educación artística desde la experiencia creativa. Arte y Políticas de Identidad, 14, 79-95. https://search.proquest.com/docview/1862887871? accountid=14542

Available:

Moreno, M. P. (2016). La cocina española antigua de Emilia Pardo Bazán: Dulce venganza e intencionalidad múltiple en un recetario ilustrado. La Tribuna: Cadernos de Estudos da Casa-Museo Emilia Pardo Bazán, 4, 243-251.

Orden ECD/65/2015, de 21 de enero, por la que se describen las relaciones entre las competencias, los contenidos y los criterios de evaluación de la educación primaria, la educación secundaria obligatoria y el bachillerato. (BOE núm. 25, de 29 de enero de 2015, 6986-7003).

Orden ECD/563/2016, de 18 de abril, por la que se modifica la Orden EDU/849/2010, de 18 de marzo, por la que se regula la ordenación de la educación del alumnado con necesidad de apoyo educativo y se regulan los servicios de orientación educativa en el ámbito de gestión del Ministerio de Educación, en las ciudades de Ceuta y Melilla. (BOE núm. 95, de 20 de abril de 2016, 26679-26681).

Orden ECD/1361/2015, de 3 de julio, por la que se establece el currículo de Educación Secundaria Obligatoria y Bachillerato para el ámbito de gestión del Ministerio de Educación, Cultura y Deporte, y se regula su implantación, así como la evaluación continua y determinados aspectos organizativos de las etapas. (BOE núm. 163, de 9 de julio de 2015, 56936-56962).

Ortega, O. (2016). Dinámica de grupos: técnicas de organización de eventos. Ecos Ediciones.

Pardo Bazán, E. (1913). La cocina española antigua. Facsímil. Editorial Maxtor (2012).

\section{info@icate.org}




\section{3rd International Conference on Advanced Research in Teaching and Education}

Pardo Bazán, E. (1918). La cocina española moderna. Facsímil. Editorial Maxtor (2010).

Parra, C. H. (1993). El patriarcado y la inevitable subyugación femenina en "Los Pazos de Ulloa". Utah Foreign Language Review, 5. Available: https://search.proquest.com/docview/1626233398?accountid=14542

Rodríguez, A. R. (1982). La Cuestión Feminista en los ensayos de Emilia Pardo Bazán. (spanish Text) (Order No. 8216911). Available from ProQuest Dissertations \& Theses Global.

(303084263).

Available: https://search.proquest.com/docview/303084263?accountid=14542

Rojas Yedra, R. (2017). Ideología y estética en Los Pazos de Ulloa. Revista de Filología de la Universidad de La Laguna, 35, pp. 251-267.

Sánchez, P. (2007). Morriña de Emilia Pardo Bazán: la cuestión femenina. Cuadernos de Historia Contemporánea, 13.

Simón Palmer, M. C., y Sauret Guerrero, M. T. (2010). Del fogón a la pluma: Pioneras de la literatura culinaria: Emilia Pardo Bazán y Carmen de Burgos. Bethesda: ProQuest LLC, Ministerio de Ciencia e Innovación; Servicio de Publicaciones Universidad de Málaga. Available: https://search.proquest.com/docview/1626350725?accountid=14542

Sotelo Vázquez, M. (1998). Emilia Pardo Bazán: Entre el romanticismo y el realismo. In Del romanticismo al realismo. Actas del I Coloquio de la Sociedad de Literatura Española del Siglo XIX, pp. 429-442, Universitat de Barcelona.

Theophano, J. (2016). Eat my words: Reading women's lives through the cookbooks they wrote. St. Martin's Griffin 